\title{
The Computer Science Attitude and Identity Survey (CSAIS): A Novel Tool for Measuring the Impact of Ethnic Identity in Underrepresented Computer Science Students
}

\section{Dr. Alicia Nicki Washington, Winthrop University}

Dr. Nicki Washington is an Associate Professor in the Department of Computer Science and Quantitative Methods at Winthrop University in Rock Hill, SC. Prior to this, she was an Associate Professor in the Department of Computer Science at Howard University in Washington, DC.

She received a B.S. in Computer Science from Johnson C. Smith University and a M.S. and Ph.D. in Computer Science from North Carolina State University.

Her research interests include the use of culturally-relevant pedagogy to increase the participation and performance of underrepresented students in computer science.

Dr. Shaefny Grays , North Carolina State University

Dr. Sudipta Dasmohapatra, North Carolina State University

Dr. Sudipta Dasmohapatra is an associate professor in analytics at the Institute for Advanced Analytics at NC State University, Raleigh, NC. The Institute was pivotal in creating the nation's first Masters in Advanced Analytics program. She also holds a joint appointment in the Department of Forest Biomaterials in the College of Natural Resources at the university. Dr. Dasmohapatra's research focuses on the application of analytical models for solutions to environmental problems. In addition to mentoring $\mathrm{PhD}$ and MS students, Dr. Dasmohapatra annually advises about 20 student teams working on industry sponsored advanced analytics projects. 


\title{
The Computer Science Attitude and Identity Survey (CSAIS): A Novel Tool for Measuring the Impact of Ethnic Identity in Underrepresented Computer Science Students
}

\begin{abstract}
As computer science continues to permeate every aspect of society, the number of students of color adequately prepared for, choosing to pursue, and successfully completing computer science (CS) undergraduate programs is still dismal. CS education research has focused heavily on understanding why students of color don't pursue computer science and identifying better ways to instruct, retain, and engage them. While there are several tools that measure student interest in, knowledge of, and attitude towards CS, there are none that assess the direct impact of ethnic identity on their perceptions of the field and decisions to pursue it.

To this extent, the Computer Science Cultural Attitude and Identity Survey (CSAIS) was developed to measure five important constructs that influence the attitudes and identity of undergraduate students of color in computer science: confidence, interest, gender, professional, and identity. The tool currently targets freshmen and sophomores either entering the university as first-time college students or enrolling in their first CS course. It was validated using current and former computer science students of color. The results indicated that the tool, specifically the identity construct, is a valid and reliable measure of ethnic identity in relation to CS.
\end{abstract}

\section{Introduction}

While computer science (CS) continues to permeate every aspect of society, the number of highschool students of color that are adequately prepared to enroll in university computer science programs is still low. According to the College Board's 2015 results for the AP Computer Science test, only 3.8\% of all test takers were African-American, 3.7\% Hispanic, $0.4 \%$ Native American, and 3.6\% Other Underrepresented Minorities ${ }^{24}$. The most recent results of the Taulbee Survey also indicate the number of students of color completing CS baccalaureate degrees is still dismal, comprising a total of $12 \%$ of all CS graduates, with $3.2 \%$ AfricanAmerican, $6.8 \%$ Hispanic, $0.4 \%$ Native American, and $1.7 \%$ Interracial $^{23}$.

By the year 2020 , over $50 \%$ of all jobs will require some level of computing ${ }^{29}$. However, it is the only field that will not have enough students in the pipeline to fill these positions. In addition, by the year 2020, African-Americans and Hispanics alone will comprise approximately $40 \%$ of the U.S. workforce ${ }^{15}$. In order to increase the number of CS graduates, special emphasis must be placed on students of color, whose representation in the country is significantly growing, yet is still dismal in the discipline.

A number of national efforts and research are currently focused on not only exposing more students of color to CS, but also preparing them for higher-level CS courses and ultimately, CS 
undergraduate programs and careers ${ }^{14}$. Much of this research focuses on identifying hindrances to student participation (e.g. lack of diversity and exposure, "boring" content, and perceptions as a White and Asian male field) and solutions (e.g. culturally-relevant curriculum, ethnicallyrelevant role models, etc.) that help CS become as relevant to students' daily lives as possible $5,6,25,26$.

Currently, there is no tool that measures how students view themselves, specifically their ethnic identity, in the context of CS. While there are several tools that measure student attitudes toward and interest in CS, none measure the important construct of identity. The Computer Science Attitude and Identity Survey (CSAIS) is the first tool that is designed to measure attitudes towards CS and ethnic identity in the context of CS. The tool specifically targets students of color in their first year of studies.

Using this tool, researchers can quantify, track, and assess how successful K-12 efforts targeting students of color are, over time, in meeting the intended goal of increasing CS participation. This research was focused on the development and validation and reliability testing of the CSAIS. It leverages questions from prior CS-related and ethnic identity surveys to develop successful measures for identifying ethnic identity in CS. Initial validation and reliability testing results indicate that the tool is both valid and reliable.

\section{Related Work}

The review of the literature identified several computing and engineering-related surveys over the last 15 years that measure students' attitudes toward and interest in CS and engineering. Table 1 presents the most related surveys, participant grade levels, constructs measured, and measurement scale.

Table 1. Computing and Engineering-Related Surveys

\begin{tabular}{|l|l|l|l|}
\hline \multicolumn{1}{|c|}{ Name } & \multicolumn{1}{|c|}{$\begin{array}{c}\text { Grade } \\
\text { Level(s) }\end{array}$} & \multicolumn{1}{|c|}{ Constructs } & $\begin{array}{c}\text { Measurement } \\
\text { Scale }\end{array}$ \\
\hline $\begin{array}{l}\text { Computing } \\
\text { Attitude Survey }\end{array}$ & Undergraduate & $\begin{array}{l}\text { Transfer, Interest, Problem-Solving, } \\
\text { Real-World Connections, \& Fixed } \\
\text { Mindset }\end{array}$ & 5-point Likert \\
\hline $\begin{array}{l}\text { CS Attitude } \\
\text { Survey }\end{array}$ & Undergraduate & $\begin{array}{l}\text { Confidence, Attitude, Gender, } \\
\text { Usefulness, \& Motivation }\end{array}$ & 5-point Likert \\
\hline $\begin{array}{l}\text { Engineering } \\
\text { Attitude Survey }\end{array}$ & Undergraduate & $\begin{array}{l}\text { Confidence, Interest, Attitude, \& } \\
\text { Understanding }\end{array}$ & 5-point Likert \\
\hline $\begin{array}{l}\text { Engineering } \\
\text { Motivation Survey }\end{array}$ & Undergraduate & $\begin{array}{l}\text { Attainment, Interest, Cost, Utility Value, } \\
\text { \& Expectation of Success }\end{array}$ & 7-point Likert \\
\hline $\begin{array}{l}\text { Engineering } \\
\text { Students' Attitudes } \\
\text { toward Computer } \\
\text { Science }\end{array}$ & Undergraduate & $\begin{array}{l}\text { Confidence, Interest, Gender, } \\
\text { Usefulness, \& Professional }\end{array}$ & 4-point Likert \\
\hline $\begin{array}{l}\text { Freshman } \\
\text { Engineering } \\
\text { Attitude Survey }\end{array}$ & Undergraduate & $\begin{array}{l}\text { Communication Skills, Knowledge } \\
\text { Integration, Life-Long Learning, Team } \\
\text { Expectations, \& Technical Skills }\end{array}$ & 5-point Likert \\
\hline
\end{tabular}




\begin{tabular}{|c|c|c|c|}
\hline $\begin{array}{l}\text { High School } \\
\text { Students' Attitude } \\
\text { to Engineering } \\
\text { Scale }^{11}\end{array}$ & High School & $\begin{array}{l}\text { Confidence, Career, Self-Efficacy, } \\
\text { Academic History, Knowledge, \& } \\
\text { Demographic }\end{array}$ & 6-point Likert \\
\hline $\begin{array}{l}\text { Information } \\
\text { Technology } \\
\text { Attitude Survey } \\
\end{array}$ & $\begin{array}{l}\text { High School, } \\
\text { Undergraduate }\end{array}$ & $\begin{array}{l}\text { Confidence, Interest, Gender, } \\
\text { Usefulness, \& Professional }\end{array}$ & 4-point Likert \\
\hline $\begin{array}{l}\text { Middle School } \\
\text { Students' Attitude } \\
\text { to Mathematics, } \\
\text { Science, and } \\
\text { Engineering }\end{array}$ & Middle School & $\begin{array}{l}\text { Attitude, Knowledge, Academic } \\
\text { Performance, \& Engineering } \\
\text { Discussions }\end{array}$ & 6-point Likert \\
\hline $\begin{array}{l}\text { Pittsburgh } \\
\text { Engineering } \\
\text { Attitude Scale- } \\
\text { Revised }^{9}\end{array}$ & Undergraduate & $\begin{array}{l}\text { General Impressions, Financial } \\
\text { Influences } \\
\text { Societal Contributions, Social Prestige, } \\
\text { Enjoyment, Career, \& Parental Pressure }\end{array}$ & 5-point Likert \\
\hline $\begin{array}{l}\text { STARS Outreach } \\
\text { Computing } \\
\text { Attitude Survey }^{21}\end{array}$ & $\begin{array}{l}\text { Middle } \\
\text { School, High } \\
\text { School }\end{array}$ & N/A & 5-point Likert \\
\hline $\begin{array}{l}\text { Student Attitude } \\
\text { Survey }^{13}\end{array}$ & Undergraduate & $\begin{array}{l}\text { Problem-Solving, Technical Roles, } \\
\text { Financial Issues, Ethics, Environmental } \\
\text { Impact, Sustainability, \& Diversity }\end{array}$ & 5-point Likert \\
\hline $\begin{array}{l}\text { Student Attitudes' } \\
\text { toward STEM } \\
\text { Survey }^{2}\end{array}$ & $\begin{array}{l}\text { Middle } \\
\text { School, High } \\
\text { School }\end{array}$ & $\begin{array}{l}\text { Attitude-Science, Attitude-Math, } \\
\text { Attitude-Engineering, \& } 21^{\text {st }} \text { century } \\
\text { skills }\end{array}$ & 5-point Likert \\
\hline
\end{tabular}

Many of the surveys extend from others that are listed. While several measure constructs that are important to understanding student attitudes toward computer science, none of them target underrepresented minority students. Furthermore, none of the surveys account for the important construct of identity, specifically ethnic identity.

Ethnic identity is defined as "that part of an individual's self-concept, which derives from knowledge of membership of a social group (or groups) together with the emotional significance attached to that membership. ${ }^{18,19,22 \text { " }}$ Most often, the sense of belonging and attachment to the group commonly defines the term ethnic identity. Research suggests that ethnic identity, including the presence of role models of the same ethnicity, directly influences the self-efficacy of minorities in career choices and development, health behaviors, and more ${ }^{8,28}$.

Of the 15 surveys reviewed in Table 1, none of these attempt to measure ethnic identity as a construct. The closest surveys that measure any external influence are the Middle School and High School Students' Attitude to Engineering Scales, which ask who has discussed engineering as a career option with students ${ }^{11}$ and the Pittsburgh Engineering Attitude Scale-Revised, which measure the parental pressure placed on students to pursue engineering 9 .

With recent national focus on increasing diversity in computer science ${ }^{26}$, development of culturally-relevant pedagogy, and the identification of ethnically-relevant role models, ${ }^{5,6,14,25}$ an 
assessment is necessary that can be used to measure the need for or impact of such efforts on student participation in the discipline. None of the aforementioned studies provide any measurement of this, and how one's ethnic identity influences minority student pursuit of computer science degrees.

While the CSAIS extends from two different surveys, it is the first of its kind to measure ethnic identity as it pertains to minority student attitudes in computer science or any engineering-related field.

\section{Instrument Development}

Based on the review of the literature, the following five constructs were identified:

1. Confidence-Student confidence in his/her ability to learn CS.

2. Interest-Student interest in CS.

3. Gender-Student perceptions of CS as a male-dominated field.

4. Professional-Student perceptions of CS professionals.

5. Identity-Student beliefs about CS in relation to his/her ethnicity.

Of particular interest to this work was the identification of the identity construct. The CSAIS extends from the Engineering Students' Attitudes toward CS Survey, which was designed for first year CS majors and non-majors in a university School of Engineering ${ }^{12}$. The survey measures five constructs (confidence, interest, gender, usefulness, and professionalism) using a four-point Likert scale ${ }^{12}$. Since the tool was proven both reliable and valid, the CSAIS uses the previously validated questions for its corresponding constructs. Table 2 lists the questions from this tool that were used in the CSAIS.

\section{Table 2. Construct Survey Questions ${ }^{12}$}

\section{Confidence Construct}

1. I am comfortable with learning computing concepts.

2. I have little self-confidence when it comes to computing courses.

3. I do not think that I can learn to understand computing concepts.

4. I can learn to understand computing concepts.

5. I can achieve good grades ( $\mathrm{C}$ or better) in computing courses.

6. I am confident that I can solve problems by using computer applications.

7. I doubt that I can solve problems by using computer applications.

Interest Construct

1. I would not take additional computer science courses if I were given the opportunity.

2. I think computer science is boring.

3. I hope that my future career will require the use of computer science concepts.

4. The challenge of solving problems using computer science does not appeal to me.

5. I like to use computer science to solve problems.

6. I do not like using computer science to solve problems.

7. The challenge of solving problems using computer science appeals to me.

8. I hope that I can find a career that does not require the use of computer science concepts.

9. I think computer science is interesting. 
10. I would voluntarily take additional computer science courses if I were given the opportunity.

Gender Construct

1. I doubt that a woman could excel in computing courses.

2. Men are more capable than women at solving computing problems.

3. Computing is an appropriate subject for both men and women to study.

4. It is not appropriate for women to study computing.

5. Men produce higher quality work in computing than women.

6. Men are more likely to excel in careers that involve computing than women are.

7. Women produce the same quality work in computing as men.

8. Men and women are equally capable of solving computing problems.

9. Men and women can both excel in computing courses.

Professional Construct

1. A student who performs well in computer science will probably not have a life outside of computers.

2. A student who performs well in computer science is likely to have a life outside of computers.

3. Students who are skilled at computer science are less popular than other students.

4. Students who are skilled at computer science are just as popular as other students.

A four-point Likert scale was used for the CSAIS survey, to ensure participants chose a positive or negative response to each question. In addition to constructs 1-4, ten questions were developed for the identity construct (five positively-phrased and five negatively-phrased). Table 3 lists the survey questions pertaining to the identity construct. Questions were derived from the Multigroup Ethnic Identity Measure (MEIM), a well-known survey for measuring ethnic identity according to the following factors: ethnic identity search and affirmation, commitment, and sense of belonging. ${ }^{18,19,20}$

\section{Table 3. Identity Construct Questions}

\begin{tabular}{|c|c|}
\hline Question 1 & $\begin{array}{l}\text { I am active in organizations or social groups that include mostly members of } \\
\text { my own ethnic group. }\end{array}$ \\
\hline Question 2 & $\begin{array}{l}\text { I am not active in organizations or social groups that include mostly members } \\
\text { of my own ethnic group. }\end{array}$ \\
\hline Question 3 & I feel a strong attachment towards my own ethnic group. \\
\hline Question 4 & Ido not feel a strong attachment towards my own ethnic group. \\
\hline Question 5 & I have role models in computer science who look like me. \\
\hline Question 6 & Ido not know any minority computer seientists. \\
\hline Question 7 & I was encouraged to pursue a computer science degree. \\
\hline Question 8 & Iwas not encouraged to purstle a computer science degree. \\
\hline Question 9 & $\begin{array}{l}\text { Ibelieve my performance in computer science courses will reflect on my } \\
\text { race/ethnicity. }\end{array}$ \\
\hline Question 10 & $\begin{array}{l}\text { Ido not believe my performance in computer science courses will reflect on } \\
\text { my racelethnicity. }\end{array}$ \\
\hline
\end{tabular}


Questions 1-4 are directly based on MEIM questions. Questions 5-10 are non-MEIM questions that are directly related to CS in the context of the two aforementioned MEIM factors (ethnic identity search and affirmation, commitment, and sense of belonging). These question pairs focused on the identification of ethnically relevant computer scientists (role models), active participation in ethnically-relevant organizations and social groups, encouragement to pursue CS, and perceptions about performance with respect to one's race/ethnicity.

A total of 40 randomly-ordered questions were included in the CSAIS. Demographic information (race/ethnicity and gender) was also collected. The survey was administered in two parts. In Part I, participants completed the survey. In Part II, participants were asked to select which questions they identified as confusing, misleading, or unnecessary. They were also provided the opportunity to comment on each question. The research team used this information to better understand the quantitative results of the research.

\section{Participants}

The CSAIS survey was administered to 65 participants in the Fall 2015 semester. Participants included current first-year CS undergraduates and CS professionals of color. For non-students, participants were instructed to complete the survey from their original perspective as a first-year student. CS professionals of color were included in the research, because the purpose of this work was to verify and validate the tool, not the actual results of the survey. The instruction to complete using their initial perspectives as first-year undergraduates, not current graduates, was acceptable for the nature of this research. Each participant received the appropriate IRBapproved letter identifying the purpose and optional nature of the research, expectations, and contact information.

\section{Analysis and Results}

The survey results within the ethnic identity construct were first analyzed for consistency of responses. Each question and its opposite mate were analyzed to determine if aggregate results matched. Those question pairs that did not result in a $+/-$ of 9 for total in responses were flagged for further investigation. Questions 9 and 10 were the only pair flagged for further investigation:

\section{I have role models (39 strongly agree, somewhat agree, agree) I do not know any minority computer scientists (49 strongly disagree, somewhat)}

Next, construct validity was measured using principal component analysis (PCA). PCA is a data reduction technique used to identify a smaller number of uncorrelated variables (principal components) that are easier to identify and analyze than the larger data set. Completion of the PCA resulted in the identification of three principal components, as shown in Table 4. Correlation values above 0.5 are deemed significant. According to the results of the PCA, Question 6 was removed from the final model, as it did not fit well within it. 
Table 4. Principal Component Analysis Results

\begin{tabular}{|l|l|l|l|}
\hline \multirow{2}{*}{ Question } & \multicolumn{3}{|l|}{ Principal Component } \\
\cline { 2 - 4 } & 1 & 2 & 3 \\
\hline Q5 & .78 & & \\
\hline Q3 & .75 & & \\
\hline Q7 & .73 & & \\
\hline Q1 & .53 & & \\
\hline Q2 & & .82 & \\
\hline Q8 & & .76 & \\
\hline Q4 & & .67 & .88 \\
\hline Q9 & & & -.69 \\
\hline Q10 & & & \\
\hline
\end{tabular}

Principal Component 1 is strongly correlated with four of the original questions: Q1, Q3, Q5, and Q7. This implies that the results of these questions vary together. For example, if one has more ethnically-relevant role models in CS then he/she will be more active in ethnically-relevant organizations and social groups, feel a stronger attachment to his/her own ethnic group, and be more encouraged to pursue CS. Because questions 3, 5, and 7 have higher correlations, Principal Component 1 can be viewed as measuring the impact of role models, attachment, and commitment (as defined by ethnic identity) on student participation in $\mathrm{CS}^{18}$. From these results, it is clear that the questions loading on Principal Component 1 have the maximum variance and are the most appropriate to measure the ethnic identity construct. All questions removed from the survey are indicate in Table 3 with a strike-through.

To test the reliability of the remaining questions within the ethnic identity construct, Cronbach's alpha was calculated as 0.66 . While this is slightly less than the traditionally-accepted value of 0.7 , research by Nunnally states that newly-developed measures are considered acceptable when the threshold is $0.6^{17}$. Since the CSAIS, specifically the ethnic identity construct, is a newlydeveloped measure within CS, the value of the Cronbach's alpha indicates the questions within the construct are reliable.

The Part II responses were reviewed, in order to better understand the results of the quantitative analysis. Of particular interest was the removal of both questions 9 and 10. Many participants noted the wording of this was confusing. However, many participants also expressed that they did not believe their performance was a reflection of their race, but rather themselves only. Based on research regarding stereotype threat ${ }^{14}$, and the demographic of majority of the participants, it was questionable if question 9 should be removed completely from the survey. Specifically, the concern was if more current first-year students of color would answer this question differently. This question is flagged for possible inclusion in the future revision of the test and subsequent validation and reliability testing.

\section{Conclusion}

As the national focus on CS continues to grow, so does the need for more students of color in the field. Research in CS education includes various strategies for increasing the participation of 
underrepresented students in CS. However, there are no tools that currently measure the ethnic identity of students as it relates to CS, or any engineering-related field for that matter. The Computer Science Attitude and Identity Survey (CSAIS) is the first tool designed for students of color to measure their ethnic identity in relation to CS. It can be used in a variety of settings to quantitatively measure how various interventions and strategies can help improve the attitudes towards and identities of students of color in CS.

Current efforts include revisions of test questions, based on participant feedback and researcher suggestions, to make them as clear as possible. The survey questions from the confidence, gender, professionalism, and interest constructs are also being revised, based on these responses, for clarity. The test will be administered again, with measurements collected across all constructs, to ensure it still maintains reliability and validity. In addition, the demographic portion is being revised to include questions that identify participants' past experiences in CS. Finally, the research team is researching the administration of the survey at the first-year level for undergraduates versus the end of $12^{\text {th }}$ grade.

\section{References}

1. Brown, P.R. \& Matusovich, H.M. (2013). Unlocking student motivation: Development of an engineering motivation survey. In the Proceedings of the $120^{\text {th }}$ Annual Conference and Exposition of the American Society for Engineering Education.

2. Dorn, B. \& Tew, A. E. (2015). Empirical validation and application of the Computing Attitudes Survey. Computer Science Education, 25(1):1-36.

3. Faber, M., Unfried, A., Wiebe, E.N., Corn, J. \& Collins, T.L. (2013). Student attitudes toward STEM: The development of upper elementary school and middle/high school student surveys. In the Proceedings of the $120^{\text {th }}$ American Society of Engineering Education Conference.

4. Forssen, A. V., Moskal, B. M., \& Harriger, A. R. (2011). Measuring the impact of a high school intervention on students' attitudes in information technology: Validation and use of an attitude survey. In the Proceedings of the American Society for Engineering Education.

5. Goode, J. 2010. Connecting K-16 curriculum \& policy: Making computer science engaging, accessible, \& hospitable for underrepresented students. In the Proceedings of the 40th SIGCSE Technical Symposium on Computer Science Education.

6. Goode, J. 2008. Computer science segregation: Missed opportunities. The Voice. 4(2).

7. Graham, J. M., \& Caso, R. (2002). Measuring engineering freshman attitudes and perceptions of their first year academic experience: The continuing development of two assessment instruments. In the Proceedings of the 32nd Annual Frontiers in Education Conference.

8. Gushue, G.V. and Whitson, M.L. (2006). The relationship among support, ethnic identity, career decisions and self-efficacy, and outcome expectations in African-American high school students. Journal of Career Development, 33(2), 112-124.

9. Hilpert, J. C., Stump, G., \& Husman, J. (2010). Pittsburgh engineering attitudes scale - revised: Evidence for an improved instrument. In the Proceedings of the 40th ASEE/IEEE Frontiers in Education Conference, Washington, D.C. 
10. Hirsch, L. S., Carpinelli, J. D., Kimmel, H., Rockland, R., \& Bloom, J. (2007). The differential effects of pre-engineering curricula on middle school students' attitudes to and knowledge of engineering careers. In the Proceedings of the 37th ASEE/IEEE Frontiers in Education Conference

11. Hirsch, L. S., Gibbons, S.J., Kimmel, H., Rockland, R., \& Bloom, J. (2003). High school students' attitudes to and knowledge about engineering. In Proceedings of the 33rd Annual Conference for Frontiers in Education, Westminster, CO.

12. Hoegh, A. \& Moskal, B. M. (2009). Examining science and engineering students' attitudes toward computer science. In the Proceeding of the 39th ASEE/IEEE Frontiers in Education Conference, San Antonio, TX.

13. Lathem, S. A., Neumann, M. D., \& Hayden, N. (2011). The socially responsible engineer: Assessing student attitudes of roles and responsibilities. Journal of Engineering Education, 100(3), 444-474.

14. Margolis, J., Estrella, R., et.al. (2008). Stuck in the shallow end: Education, race, and computing. Cambridge, Massachusetts: The MIT Press.

15. National Academy of Engineers. The Engineer of 2020 Project Prospectus.

16. Nocito-Gobel, J., Collura, M. A., Daniels, S., \& Orabi, I. I. (2005). Are attitudes toward engineering influenced by a projected-based introductory course? In the Proceedings of the 2005 American Society for Engineering Education Conference and Exposition, Portland, OR.

17. Nunnally, J. C. (1988). Psychometric Theory. New Jersey: McGraw-Hill, Englewood Cliffs.

18. Phinney, J.S. and Ong, A.D. (2007). Conceptualization and measurement of ethnic identity: Current status and future directions. Journal of Counseling Psychology, 54(3), 271-281.

19. Phinney, J. (1992). The Multigroup ethnic identity measure: A new scale for use with diverse groups. Journal of Adolescent Research, 7(2), 156-176.

20. Roberts, R.E., Phinney, J.S., et. al. (1999). The structure of ethnic identity of youth adolescents from diverse ethnocultural groups. Journal of Early Adolescence, 19(3), 301-322.

21. STARS Outreach Computing Attitude Survey. Retrieved from http://starscomputingcorps.org/sites/default/files/ms_hsoutreach_survey_uncc.docx.

22. Tajfel, H. (1981). Human groups and social categories. Cambridge, England: Cambridge University Press.

23. Taulbee Survey. Computing Degrees and Enrollment Trends. Retrieved from http://cra.org/wpcontent/uploads/2015/06/2014-Taulbee-Survey.pdf

24. The College Board. Retrieved from http://research.collegeboard.org/programs/ap/data/participation/ap2015

25. Washington, A.N. and Burge, L. (2016) Closing the gap: Using cultural relevance to attract and retain African-American and Hispanic students in the computer science pipeline. Journal of Negro Education, pending publication.

26. Washington, A. N. and Burge, L. (2013) Increasing and improving K-12 computer science education through partnerships. In the Proceedings of the Hawaii University International Conference on Education and Technology, USA. 
27. Williams, L., McDowell, C., Nagappan, N., Fernald, J., \& Werner, L. (2003). Building pair programming knowledge through a family of experiments. In the Proceedings of the 2003 International Symposium on Emprical Software Engineering, 143-152.

28. Yancey, A.K., Siegel, J.M., \& McDaniel, K.L. (2002). Role models, ethnic identity, and health-risk behaviors in urban adolescents. Archives of Pediatrics and Adolescent Medicine, 156(1), 55-61.

29. Bureau of Labor Statistics. Retrieved from http://www.bls.gov/. 